\title{
Anatomical and Morphological Features of Seeds in Portulaca
}

\author{
InSun Kim* \\ Department of Biology, College of Natural Sciences, Keimyung University, Daegu 704-701, Korea
}

*Correspondence to:

Kim IS,

Tel: +82-53-580-5305

Fax: +82-53-580-5305

E-mail: botany@kmu.ac.kr

Received November 9, 2012

Revised December 7, 2012

Accepted December 10, 2012
The anatomy and morphology of seeds from 10 Hawaiian Portulaca taxa were examined to explore patterns of variation among the taxa, and to evaluate their phylogenetic relationships. Features of seeds were assessed employing microtechnique procedures, statistical analysis, and scanning electron microscopy (SEM). Anatomically, the orientation of embryo was consistent across taxa, and all seeds examined had central nutritive tissue and integuments comprising the peripheral embryo. Seeds were generally small, circular to ovoid in shape, and either smooth or rough-surfaced, with tubercules. Variation in seed size was noted, although minimal within small seeded group. The size of seeds ranged from $0.50 \sim 1.26 \mathrm{~mm}$ in length, and $0.55 \sim 1.34 \mathrm{~mm}$ in width, with similar weights. Seeds were distinguished by the sculpture and arrangement of the testa epidermis and the way in which their stellulate-tessellate cells uniquely fit together. Using a multiple range test (ANOVA), two groups were established by seed characteristics. The SEM also demonstrated morphological differences in testa sculpturing. The results obtained confirm the usefulness of seed characteristics in the identification of the species examined, and furthermore, allow for the separation of the Hawaiian Portulaca into two groups.

Key Words: Hawaiian Portulaca, Morphology, Seed, Testa sculpturing

\section{INTRODUCTION}

Species of Portulaca (portulacas) are annual or perennial, some are polytypic, and most of them are succulent to various degrees in leaves, stems, or even roots. The genus Portulaca is in the family Portulacaceae and two highly variable species, the ornamental P. grandiflora and the cosmopolitan P. oleracea, are well-known. The portulacas are widely distributed and they occupy a wide range of areas from sea level to high elevation. One of the contributing factors for the achievement of wide geographical distribution of Portulaca is the nature of their seeds (Matthews \& Levins, 1985a, 1985b, 1986; Kim \& Carr, 1990b; Matthews \& Ketron, 1991; Matthews et al., 1991, 1992, 1994). The seeds are very small, mostly less than $1 \mathrm{~mm}$ in diameter, and numerous. One study revealed up to 292,010 seeds produced by one plant of $P$. pilosa during one growing season (Zimmerman, 1976). However, there is no evidence found in Portulaca that seeds have obvious dispersal mechanism or any anatomical modifications for dissemination. Although the seeds are very small, they are not well adapted to wind dispersal because they do not possess any structures which could help them to disseminate by wind. The most accepted theory concerning dispersal of Portulaca seeds is that man is the main agent (Myanishi \& Cavers, 1980), although the bird has been suggested as the agent for the introduction of cosmopolitan species in other areas (Chamorro et al., 2012).

In general, species of the Portulaca are not of any great economic importance. However, much attention has been drawn to Portulaca growing in Hawaii since a comprehensive study of biosystematics and ultrastructure of Hawaiian native and introduced species (Yun, 1989). The cosmopolitan species $P$. oleracea and widely distributed $P$. pilosa have been particularly focused, because they have been speculated as

@ This is an open-access article distributed under the terms of the Creative Commons Attribution Non-Commercial License (http://creativecommons.org/licenses/by-nc/3.0) which permits unrestricted noncommercial use, distribution, and reproduction in any medium, provided the original work is properly cited.

Copyright (C) 2012 by Korean Society of Microscopy 
the plausible parental species for the ornamental Portulaca cultivars (Kim \& Carr, 1990a). In a study of reproductive biology of the Hawaiian Portulaca (Kim \& Carr, 1990b), and their cytogenetics and hybridization (Kim \& Carr, 1990a), structural features, including seed characteristics, a couple of unknown species and cultivars were described and their phylogeny have been roughly speculated. In the present study, the anatomy and morphology of seeds from 10 Hawaiian Portulaca taxa, including two unknown species, were examined in order to explore the pattern of variation and to evaluate the phylogenetic relationships among them. This paper aims at providing some anatomical and morphological information that could be of phylogenetic value within Portulaca growing in Hawaii.

\section{MATERIALS AND METHODS}

Approximately 30 100 mature seeds were collected from three broad-leaved species (P. oleracea, P. lutea, $P$. molokiniensis), five cylindrical-leaved taxa (P. pilosa, P. villosa, $P$. sclerocarpa, $P$. sp. nov. $1, P$. sp. nov. 2) and two cultivars (broad-leaved Cultivar 1, cylindrical-leaved Cultivar 2). Fresh seeds collected from those taxa as in Yun (1989) were used for both qualitative and quantitative data during the study. Seeds were processed by the following microtechnique procedures for anatomical studies. They were fixed for 12 24 hrs in 6\% glutaraldehyde followed by dehydration in a graded series of ethyl alcohol-tertiary butyl alcohol solutions, infiltration with parawax and embedding in paraplast. Sections were made at 5 10 $\mu \mathrm{m}$ thickness, overstained with $1 \%$ safranin and counterstained with Fast Green. They were also fixed with $3 \%$ glutaraldehyde in $0.1 \mathrm{M}$ sodium cacodylate buffer $(\mathrm{pH}$ 6.8 7.2) and embedded in Spurr's resin. In this case, electron microscopy procedures used for Portulaca (Kim \& Fisher, 1990) were followed and thick sections of $1 \sim 2 \mu \mathrm{m}$ were made. For scanning electron microscopy, dry seeds were mounted directly on stubs using double sided adhesive tape and coated with gold/palladium in a sputter coater. A compound microscope, Zeiss Photomicroscope II (Zeiss, Oberkochen, Germany), was used to measure the size of seeds. Length and width of seeds were determined by measuring 50 seeds in ways illustrated in Fig. 1A.

Statistical analyses of a multiple range test (Waller/Duncan test, ANOVA), and t-test using Statistical Analysis System program were performed for the comparisons among taxa. Significant differences were reported when the probability was less than $0.05(\mathrm{p}<0.05)$. The Waller/Duncan test was used to establish groups among 10 taxa and the $t$ test was used to compare some characters of two taxa and to determine similarity or dissimilarity between them. All values stated to describe a given attribute throughout the paper represented mean values obtained during the basic statistical analysis.

\section{RESULTS AND DISCUSSION}

\section{Seed Anatomy}

The orientation of the embryo was consistent and all seeds examined had peripheral embryo, central perisperm, and inner and outer integument. The embryo possessed symmetrical cotyledons and encircled the nutritive tissue, perisperm. The seeds exhibited curved embryos that were positioned peripherally. Accordingly, the seeds were campylotropous and they had two well-defined cotyledons (Fig. 1A and B). The embryo occupied most of the seed volume and surrounded the central semi-transparent perisperm. The seed covering consisted of a dark colored outer integument and a membranous inner integument. The outer integument was relatively thin, ranging up to about 10 $\mu \mathrm{m}$ in most taxa. The inner integument was very thin and transparent, and had a unique pattern. Its membranous cells were arranged more or less regularly in rows with obliquely oriented bands in the wall (Fig. 1C). In species whose seeds were tuberculate or spinous, as in P. oleracea, $P$. molokiniensis (Fig. 1D-F), P. lutea (Fig. 1G-I), and P. pilosa (Fig. 2A and B), the spines or tubercles were hollow.

Embryo encircling the perisperm has been considered as the primitive state within Portulacaceae (Carolin, 1987). Seeds of Portulaca were categorized as endospermic, although a study of embryology in P. oleracea has shown that little endosperm, if any, remained in the fully mature seeds. Multiple seed coverings were not observed, but a thin inner integument which exhibited unique cell pattern was noticed. The seed coverings were considered to contribute to the principal germination control in this peripheral embryo type (Atwater, 1980). Seed structure found in this study was similar to that which has been reported in a few species of this genus previously (Yun, 1989). The findings of the present and earlier studies on Portulaca seeds supported the findings that they had shown very similar seed structure, in general, within the plant family and their close relatives.

\section{Seed Morphology}

Seeds of Portulaca were generally small, circular to ovate, and either smooth or tuberculated. Seeds were black ( $P$. oleracea and $P$. lutea), or reddish to dark brown (P. molokiniensis, $P$. villosa, $P$. sclerocarpa, $P$. sp. nov. 1 and $P$. sp. nov. 2), or metallic blue (P. pilosa), or whitish gray (Cultivar 1). In Cultivar 1, the seeds were black when inside the capsules, but turned whitish gray as soon as they were exposed to air when the capsules dehisced. The micropyle and hilum were usually visible adjacent on the seed. In fact, most of micropyles examined demonstrated the same orientation with their openings pointed toward the hilum, except in those of. P. molokiniensis. In this species, the micropyle appeared as an occluded pore (Fig. 1F) and this feature was later found to be related to the 

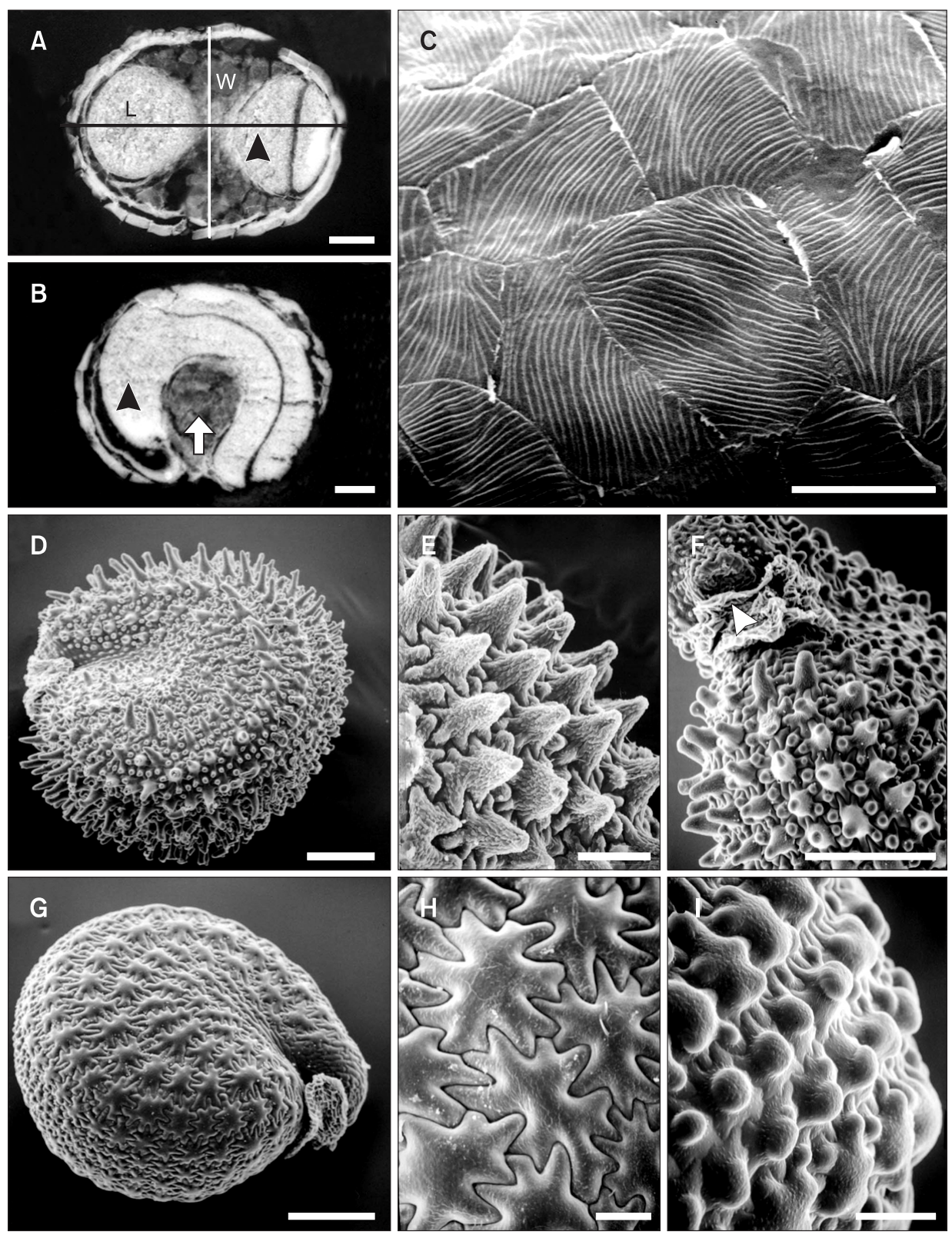

Fig. 1. Anatomy and morphology of Portulaca seeds in Group A. Peripheral embryo (arrowhead) and central perisperm (arrow) is shown in transverse (A) and paradermal section (B) of $P$. oleracea. Bar $=100 \mu \mathrm{m}$. (C) Inner integument of $P$. villosa. Bar $=10 \mu \mathrm{m}$. (D, E) Spiny seed of $P$. molokiniensis $(\mathrm{Bar}=200 \mu \mathrm{m})$ with close-up view $(\mathrm{Bar}=40 \mu \mathrm{m})$. (F) Areas of micropyle and hilum (arrowhead) in P. molokiniensis. Bar $=200 \mu \mathrm{m}$. (G) P. lutea (G, Bar $=200 \mu \mathrm{m})$ with close-up views of the side $(\mathrm{H}, \mathrm{Bar}=40$ $\mu \mathrm{m})$ and marginal aspects (I, Bar $=40 \mu \mathrm{m}$ ). $\mathrm{L}$, length; W, width. low seed germination response in this species.

Variation in seed size was noticed, although slight, within small seeded groups (Fig. 2A-I). The size of seeds ranged from $0.50 \sim 1.26 \mathrm{~mm}$ in length and $0.55 \sim 1.34 \mathrm{~mm}$ in width. They were distinguished into two groups by the leaf shape and seed sizes. In general, cylindrical-leaved group B had smaller seeds $(0.50 \sim 0.74 \times 0.55 \sim 0.80 \mathrm{~mm})$ than broad-leaved group A (0.91 1.26×0.97 1.34 mm). The smallest seeds were found in $P$. sp. nov. $1(0.53 \times 0.55 \mathrm{~mm})$ (Fig. 2 C) of group B and the largest seeds in $P$. molokiniensis $(1.26 \times 1.34 \mathrm{~mm})$ of group A.

The size and weight analyzed were positively correlated among species. Smaller seed $(0.5 \sim 0.8 \mathrm{~mm})$ were found in five taxa of group B and weighed 3.4 7.2 mg per 100 seeds, whereas seeds of three species in Group A $(0.9 \sim 1.3 \mathrm{~mm})$ weighed 11.0 22.2 mg/100 seeds. Among Portulaca studied, the bigger the seeds were, the heavier they were. The weight of 100 seeds in species of group A was $11.0 \mathrm{mg}$ in P. oleracea, $21.0 \mathrm{mg}$ in P. lutea, and $22.2 \mathrm{mg}$ in P. molokiniensis. However, it was $5.0 \mathrm{mg}$ in P. pilosa, $7.2 \mathrm{mg}$ in $P$. villosa, $6.0 \mathrm{mg}$ in $P$. sclerocarpa, $3.4 \mathrm{mg}$ in $P$. sp. nov. 1, and $6.0 \mathrm{mg}$ in $P$. sp. nov. 2. Seeds (100) of Cultivar 1 (Fig. $2 \mathrm{H}$ ) weighed $12.5 \mathrm{mg}$, but no data were available for Cultivar 2 in these characters. Results of Waller/Duncan test on those seed characteristics examined in the study were shown in Table 1.

Seeds of Portulaca have drawn much attention for their importance in distinguishing species. They were distinguished 

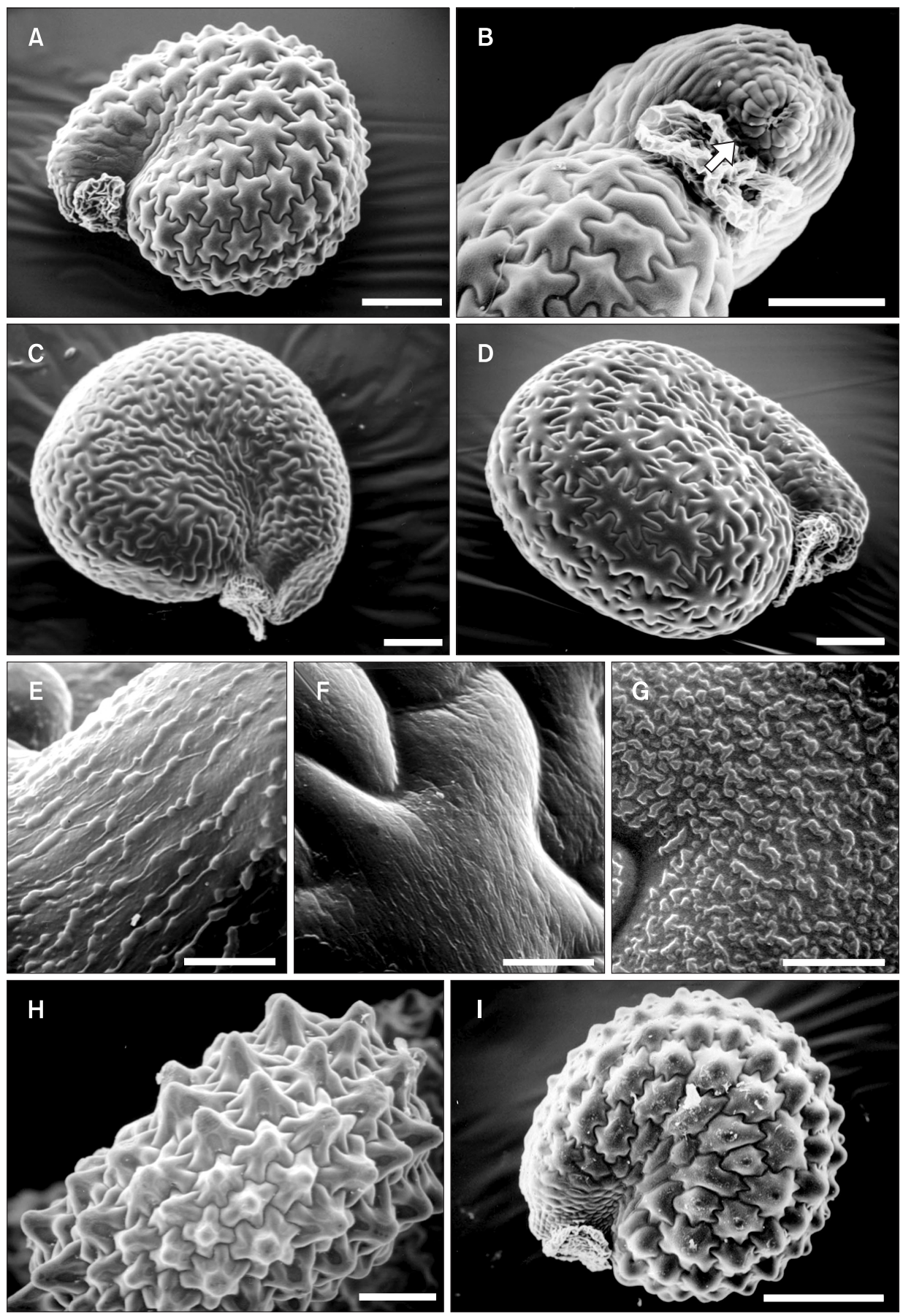

Fig. 2. Seed morphology of Portulaca in Group B and cultivars. (A) P. pilosa. Bar $=100 \mu \mathrm{m}$. (B) Areas of micropyle and hilum (arrow) in P. pilosa. Bar $=100 \mu \mathrm{m}$. (C) P. sp. nov. 1. Bar $=100 \mu \mathrm{m}$. (D) P. villosa. Bar $=100 \mu \mathrm{m}$. (E-G) Surface textures of testa epidermal cells in P. molokiniensis (E, Bar $=10 \mu \mathrm{m})$, in P. sclerocarpa $(\mathrm{F}, \mathrm{Bar}=10$ $\mu \mathrm{m})$ and in P. villosa (G, Bar $=10 \mu \mathrm{m}) .(\mathrm{H}$, I) Broad-leaved Cultivar 1 (H, Bar=100 $\mu \mathrm{m})$ and cylindrical-leaved Cultivar 2 (I, Bar=200 $\mu \mathrm{m})$. by the sculpture and arrangement of the epidermal cells of the testa. The way in which their stellulate-tessellate epidermal testa cells fit together was unique. A considerable variation in seed morphology was detected in the present study. Smooth and shining testa cells with flat surfaces were found in seeds of $P$. villosa, $P$. sclerocarpa, $P$. sp. nov. 1, and $P$. sp. nov. 2 of group B. Their testa had stellulate cells, usually $5 \sim 8$ lobed with somewhat blunt tips in each lobe. These features were consistent among the species mentioned above without any noticeable variation.

However, examination of individual cells at a higher magnification $(\times 2000)$ disclosed differences in surface structure (Fig. 2E-G). Some seeds were smooth while others showed granular surface, however, these features were not generally confined to any specific taxon. Another testa pattern was observed in two species of group A. In P. oleracea and $P$. lutea, the stellulate-tessellate cells were mostly domeshaped and the tips were stellulately lobed. The stellulate- 
Table 1. Comparison of seed characteristics of in the Hawaiian Portulaca examined

\begin{tabular}{|c|c|c|c|c|c|c|c|}
\hline \multirow{2}{*}{ Taxon } & \multicolumn{2}{|c|}{ Seed $(\mathrm{mm})$} & \multicolumn{2}{|c|}{ Waller/Duncan Seed } & \multirow{2}{*}{$\begin{array}{l}\text { Seed weight } \\
(100 / \mathrm{mg})\end{array}$} & \multirow{2}{*}{\multicolumn{2}{|c|}{ Waller/Duncan }} \\
\hline & $\mathrm{L}$ & W & $\mathrm{L}$ & $\mathrm{W}$ & & & \\
\hline \multicolumn{8}{|l|}{ Broad leaved group } \\
\hline P. oleracea & 0.91 & 0.97 & $\mathrm{D}$ & $\mathrm{D}$ & 11.0 & $\mathrm{D}$ & $\mathrm{D}$ \\
\hline P. lutea & 1.10 & 1.22 & $\mathrm{~B}$ & $\mathrm{~B}$ & 21.1 & $\mathrm{~B}$ & $\mathrm{~B}$ \\
\hline P. molokiniensis & 1.26 & 1.34 & A & A & 22.2 & A & A \\
\hline \multicolumn{8}{|c|}{ Cylindrical leaved group } \\
\hline P. pilosa & 0.64 & 0.71 & G & G & 5.0 & G & G \\
\hline P. villosa & 0.73 & 0.80 & $\mathrm{~F}$ & $\mathrm{~F}$ & 7.2 & $\mathrm{E}$ & $\mathrm{E}$ \\
\hline P. sclerocarpa & 0.74 & 0.79 & $\mathrm{~F}$ & $\mathrm{~F}$ & 7.2 & $\mathrm{~F}$ & $\mathrm{~F}$ \\
\hline$P$ sp. nov. 1 & 0.53 & 0.55 & $\mathrm{H}$ & I & 3.4 & $\mathrm{H}$ & $\mathrm{H}$ \\
\hline$P$ sp. nov. 2 & 0.50 & 0.61 & $\mathrm{H}$ & $\mathrm{H}$ & 6.0 & $\mathrm{~F}$ & $\mathrm{~F}$ \\
\hline \multicolumn{8}{|l|}{ Broad leaved group } \\
\hline Cultivar 1 & 0.98 & 1.04 & $\mathrm{C}$ & $\mathrm{C}$ & 12.5 & $\mathrm{C}$ & $\mathrm{C}$ \\
\hline \multicolumn{8}{|c|}{ Cylindrical leaved group } \\
\hline Cultivar 2 & 0.79 & 0.84 & $\mathrm{E}$ & $\mathrm{E}$ & NA & NA & NA \\
\hline
\end{tabular}

L, length; W, width; NA, not available.

tessellate cells usually had $8 \sim 10$ lobes with somewhat pointed tips. Tubercles were mostly found on the marginal cells (Fig. 1I) while the central portions of the seeds had only convex stellulate cells (Fig. 1H). Seeds with flat surfaces were occasionally observed in these species. All seeds examined in these two species possessed granulate surfaces with slight variations. The most interesting variation of testa structure was encountered in an endemic species, $P$. molokiniensis. The stellulate-tessellate cells were conspicuously tuberculate or even to spiny over the entire surface of the seed (Fig. 1D-F). Spines, approximately $40 \sim 80 \mu \mathrm{m}$ long, protruded from the center of each epidermal cell. They formed a regular array alternating with small tubercles at the stellulate tips of each cell. The spines were hollow when they were long. A slight variation was detected in this species with respect to the degree of seed spineness from different populations. All seed surfaces of $P$. molokiniensis were granulate (Fig. 1E).

Another type of variation was also noticed in three other taxa of Portulaca. In P. pilosa (Fig. 2A), testa cells were 5 7 lobed stellulate-tessellate with blunt-tips as in the other four taxa of group B. However, seeds were mostly tubercled, and these tubercles were especially prominent at the margins of the seeds. This feature was fairly consistent throughout the materials examined. Systematic variation in surface texture of individual testa epidermal cells is illustrated in Fig. 2E-G. The most granulate surface, although not shown, among all taxa examined was noted in Cultivar 1 that showed tubercles over the entire seed surface (Fig. $2 \mathrm{H}$ ). A similar seed nature was observed in Cultivar 2. The testa cells were elliptic with blunttipped lobes and the seeds were moderately tubercled over the entire surface (Fig. 2I).
Much attention has been paid to the morphology of seeds in Portulaca due to its significance in delimitating taxa. In Portulacaceae seed traits such as the structure of epidermal testa, shape of the edges and side faces of the seeds near the top of the seed stalks, and the hilum were used to differentiate members into distinct groups (Matthews \& Levins, 1986; Yun, 1989; Matthews et al., 1994). As sculpture traits or surface pattern has been considered as one of the important structural features in the genus, species were characterized by the sculpture and arrangement of the testa epidermal cells, including the lobed nature of stellulate cells and surface structures. The most notable character was the sculpture of the epidermal testa. A considerable variation was observed among species. The cells varied from being flat to orbicular, dome-shaped to elliptic, tuberculous to spinous, blunt to pointed stellulate tips in outlines, and smooth walled to granulous in their surfaces. Most features were fairly consistent in a given species, but intergradations of orbicular and tuberculous testa were observed in seeds of $P$. oleracea and P. lutea.

The results obtained confirm the usefulness of seed characters for the identification of most of the species studied and highlight the division of the genus into two sections, as has been recognized (Yun, 1989; Kim \& Carr, 1990a). Seed morphology, especially size and sculpturing of outer testa, is very useful for delimitation of the species since seeds are reported to be relatively stable in their outer morphology. In fact, seed morphology of the genus Montia within same family Portulacaceae has been almost solely used for the delimitation of subspecies (Nyananyo \& Okoli, 1987). The seed surface was found to vary, primarily by the presence or 
absence and distribution of tubercles. A comparison of the seed variation using the scanning electron microscopy has been carried out in several Portulaca species and they all agree with the tuberculate features.

As far as seed ornamentation is concerned, the current results agree with other authors (Mathews \& Levins, 1986; Nyananyo \& Okoli, 1987; Matthews et al., 1994), showing that the genus Portulaca has tuberculate seeds. The pattern of the epidermal testa cells are of particular interest, especially the outer wall. The results of the present study highlighted, to some extent, the importance of the morphology of seeds in relation to dispersal or to the establishment of new plants. The high production of seeds per capsule was an adaptation of this type of plants aimed at increasing the probability of finding an appropriate habitat as suggested in small seeds of Orobanche species (Plaza et al., 2004).

The results obtained confirm the usefulness of seed characters for the identification of most of the species examined, and highlight separating the Hawaiian Portulaca into two groups, as has been recognized. For resolving delimitation of Hawaiian endemic putative sister-species with a close affinity (Kim \& Carr, 1990a, 1990b; Baldwin \& Wagner, 2010), further phylogenetic and molecular research on reproductive features can provide new data.

\section{CONCLUSIONS}

Among the Portulaca taxa examined, two groups were established on the basis of seed size and weight. The seeds were distinguished by the sculpture and arrangement of the testa epidermis and their unique stellulate-tessellate testa cell pattern. Variation in seed size was noted, however, the weight of the seeds was comparable. Using a multiple range test (Waller/Duncan test, ANOVA), two groups were established based on seed characteristics. The broad-leaved group A includes P. oleracea, P. lutea and P. molokiniensis, while the cylindrical-leaved Group B includes P. pilosa, $P$. villosa, $P$. sclerocarpaca and two additional unknown taxa. This scheme of grouping is congruent with findings from other investigations that examine both the vegetative and reproductive attributes of the Hawaiian Portulaca. The results obtained also confirm the usefulness of seed characteristics in the identification of the species examined, and highlight the separation of the Hawaiian Portulaca into two groups.

\section{REFERENCES}

Atwater B R (1980) Germination, dormancy and morphology of the seeds of herbaceous ornamental plants. Seed Sci. Technol. 8, 523-573.

Baldwin B G and Wagner W L (2010) Hawaiian angiosperm radiations of North American origin. Ann. Bot. 105, 849-879.

Carolin R (1987) A review of the family Portulacaceae. Aust. J. Bot. 35, 383-412.

Chamorro S, Heleno R, Olesen J M, McMullen C K, and Traveset A (2012) Pollination patterns and plant breeding systems in the Galapagos: a review. Ann. Bot. 110, 1489-1501.

Kim I and Carr G D (1990a) Cytogenetics and hybridization of Portulaca in Hawaii. Syst. Bot. 15, 370-377.

Kim I and Carr G D (1990b) Reproductive biology and uniform culture of Portulaca in Hawaii. Pac. Sci. 44, 123-129.

Kim I and Fisher D G (1990) Structural aspects of the leaves of seven species of Portulaca growing in Hawaii. Can. J. Bot. 68, 1803-1811.

Matthews J F, Faircloth W R, and Allison J R (1991) Portulaca biloba Urban (Portulacaceae), a species new to the United States. Syst. Bot. 16. $736-740$

Matthews J F and Ketron D W (1991) Two new combinations in Portulaca (Portulacaceae). Castanea 56, 304-305.

Matthews J F, Ketron D W, and Zane S F (1992) The reevaluation of Portulaca pilosa and P. mundula (Portulacaceae). Sida 15, 71-89.

Matthews J F, Ketron D W, and Zane S F (1994) The seed surface morphology and cytology of six species of Portulaca (Portulacaceae). Castanea 59, 331-337.

Matthews J F and Levins P A (1985a) Portulaca pilosa L., P. mundula I. M. Johnst. and Portulaca parvula Gray in the Southwest. Sida 11, 4561.

Matthews J F and Levins P A (1985b) The genus Portulaca in the Southeastern United States. Castanea 50, 96-104.

Matthews J F and Levins P A (1986) The systematic significance of seed morphology in Portulaca (Portulacaceae) under scanning electron microscopy. Syst. Bot. 11, 302-308.

Myanishi K and Cavers P B (1980) The biology of Canadian weeds. 40. Portulaca oleracea L. Can. J. PI. Sci. 60, 953-963.

Nyananyo B L and Okoli B E (1987) Cytological and morphological studies on Nigerian species of Portulaca (Portulacaceae) in relation to their taxonomy. Fedd. Repert. 98, 583-587.

Plaza L, Fernandez I, Juan R, Pastor J, and Pujadas A (2004) Micromorphological studies on seeds of Orobanche species from the Iberian Peninsula and the Balearic Islands, and their systematic significance. Ann. Bot. 94, 167-178.

Yun I K (1989) Biosystematics and ultrastructure of Portulaca in Hawaii. Ph.D. dissertation, (University of Hawaii at Manoa, Honolulu).

Zimmerman C A (1976) Growth characteristics of weediness in Portulaca oleracea L. Ecology 57, 964-974. 